Article

\title{
Social and Solidarity Economy, Sustainable Development Goals, and Community Development: The Mission of Adult Education \& Training
}

\author{
Catalina Quiroz-Niño ${ }^{1, *}$ and María Ángeles Murga-Menoyo ${ }^{2}$ \\ 1 Escuela Internacional de Doctorado (EIDUNED), Universidad Nacional de Educación a Distancia (UNED), \\ C/Juan del Rosal, 14, 28040 Madrid, Spain \\ 2 Department of Education Theory and Social Pedagogy, Faculty of Education, Universidad Nacional de \\ Educación a Distancia (UNED), C/Juan del Rosal, 14, 28040 Madrid, Spain; mmurga@uned.es \\ * Correspondence: cquiroz1@alumno.uned.es; Tel.: +34-619-222-0580
}

Received: 29 September 2017; Accepted: 20 November 2017; Published: 24 November 2017

\begin{abstract}
A utopia of sustainable development is becoming established on the international stage. To get there, varied and complementary strategies must come into play-among them education. This trend is turning to the "Social and Solidarity Economy" (SSE), especially since the approval by the United Nations (UN) of the 2030 Agenda; the fulfilment of which demands adult education strategies and programs in line with the principles and values of sustainability. This article offers a response to that demand. It aims to carry out a reflective analysis that reveals the similarities between the principles and values of the SSE and those guiding the UN's 2030 Agenda, with its 17 Sustainable Development Goals (SDGs). Based on the results of this analysis, we will argue that training in the competencies for sustainability, essential in achieving the SDGs, is among the main functions of education within the SSE framework. Further, in order to make educational programs more sustainable, such training must be included in their operating objectives. The work uses a hermeneutic methodology based on the existing literature and gives particular attention to UNESCO's directives on training in key competencies for sustainability. The significant contribution the results make is to show: (a) the emphases of each approach and their similarities; (b) how the two are complementary; and (c) the potential, and need, for creating synergies based on their respective strengths. A further original contribution is a proposed basic guide for the design of training activities geared towards gaining the normative competency that UNESCO has identified as key to sustainability. This innovative proposal will be useful for improving the quality of adult training programs, thereby contributing to the achievement of the SDGs in communities.
\end{abstract}

Keywords: social and solidarity economy; sustainable development; social enterprises; competencies; adult education; community development

\section{Introduction}

Mindt and Reickmann [1] (p. 131) rightly state that "Sustainable development asks for new ways to organise economies. The current dominant economic systems do not only cause destruction of nature, climate change, the depletion of resources and various forms of social injustice. They are also vulnerable systems themselves". This opinion is widely shared by renowned specialists and institutions [2-5], which sets out Sustainable Development Goals (SDGs) stated in the 2030 Agenda [6] for the international community to reach in the next 15 years. A shift is necessary, therefore, in the development and cognitive paradigm that drives innovative social thinking and, in socio-economic terms, community social entrepreneurs creating resilient businesses that contribute to maintaining healthy ecosystems and promoting social justice. 
The scale of the challenge requires multiple strategies, among them, education. Its principal mission from this perspective is to train community leaders together with business owners and social entrepreneurs driven by the principles and values of sustainability. The skills, values, attitudes, and habits embedded in key sustainable competencies required must be an essential aim of such training programs [7].

The Social and Solidarity Economy (SSE) takes on the educational challenge of bringing its principles and values together with the sustainable development approach upheld by the international authority mentioned above. Recalling the well-known definition from the Brundtland Report [8], this means development that meets the needs of present-day humanity (according to the Universal Declaration of Human Rights) without compromising the needs of the planet's future inhabitants. The SSE contributes to this in driving attitudes of eco-entrepreneurship in communities and creating social businesses, cooperatives, and community initiatives based on cooperation, solidarity, reciprocity, and respect for the environment [9-11].

The purpose of this article is twofold. First, it aims to highlight the potential the SSE has to contribute to the 2030 Agenda, thanks to its commitment to transformation towards equity and social justice and the fact that each of these values is an essential part of its model for adult education. Alongside this, once the similarities between the SSE and the 2030 Agenda, and their educational approaches, have been identified, we will argue that gaining competencies for sustainability must be a stated aim of training programs in socio-economic community development within the SSE framework ("sustainabilisation"). In addition, an example of teaching practice centered in one of the Unesco competencies will be presented.

As well as shedding light on the theoretical similarities between the SSE and the 2030 Agenda, the main value of this article is in the presentation of how to include competencies for sustainability in training for socio-economic community development within the SSE framework, an innovative proposal that seeks to improve teaching practice in the training of adults in communities.

The text is divided into four sections which, in the classic hermeneutic tradition, follow the necessary order of argumentation necessary for the aims of the work. The first part presents the principles and values of the SSE, and those guiding the UN's' 2030 Agenda and its 17 SDGs. First of all, we aim to differentiate the SSE within the wider framework of the social economy and then present the points in common with the 2030 Agenda. In the second part, we analyze the role of education, from four key perspectives: ontological, operational, functional, and ecological. The third part argues for the need for the full sustainabilisation of adult education programs implemented within the SSE framework. Through this process, such programs could contribute more to the achievement of the SDGs and promote a pedagogic approach that seeks to train adults in a sustainable community development context. Finally, the fourth part, taking as a baseline, an SSE geared towards achieving the SDGs, we offer a practical example for designing training that could be included in adult education programs, with the aim of enabling people to gain competencies for sustainability.

\section{The Social and Solidarity Economy and the Challenge of the 2030 Agenda}

\subsection{Approaching the Social and Solidarity Economy (SSE)}

The Social and Solidarity Economy is part of the wider theoretical framework of the Social Economy. This section will describe the singularities of the SSE within this wider framework, after a brief introductory categorization of economic systems.

The Scottish researcher Pearce [12] (p. 25) presents a diagram which locates economic organizations in three types of systems: the private, the public, and the social. According to Pearce, the identity and characteristics of each system are directly related to the values and principles recognized and practiced by the people and organizations seeking to fulfil the end they are pursuing. In this way, the first system highlights the private sphere and its ultimate aim is to generate profit in a clearly competitive market. Institutions in the second system, meanwhile, are identified with public service, 
engaged in an economy of planned provision based on resource redistribution. The third system is identified by values of reciprocity and solidarity. Its organizations aim to achieve a balance between social and economic and environmental objectives while in pursuit of a common good.

Pearce characterizes the third system-within which the SSE is developing-as the economic model in which people are at the center of the purpose of seeking the common good and good living. The social economy model is based on values and principles guiding people and organizations towards a social mission. Its main actor is civil society, called upon to satisfy needs collaboratively. Its mission is to empower people to exercise their rights and their responsibilities, protected by a democratic constitution. The social economy is characterized, then, by its aiming to balance three factors-the economic, the social, and the environmental-within a growth model. It is important to note that this model also exists in hybrid organizations created jointly with private or public initiatives.

Table 1 shows the characteristics of each of the categories in Pearce's proposed typology, along with the criteria proposed by Dash [13] (p. 7). The latter was adapted in order to be able to compare the respective profiles, keeping in mind a foundational, functional, and operational perspective.

Table 1. Economic systems: proposed categories and criteria.

\begin{tabular}{|c|c|c|c|c|}
\hline \multirow[b]{2}{*}{ Criteria } & \multirow[t]{2}{*}{ Characteristics } & \multicolumn{3}{|c|}{ Economic System } \\
\hline & & Public Initiative & Private Initiative & Social Initiative \\
\hline \multirow[t]{2}{*}{ Foundational } & Principal actor & State & Market & $\begin{array}{l}\text { Civil society, through social } \\
\text { movements, social } \\
\text { businesses, cooperatives etc. }\end{array}$ \\
\hline & Rationale & Distribution & Competition & Cooperation, participation \\
\hline \multirow{3}{*}{ Functional } & $\begin{array}{l}\text { Relationships } \\
\text { based on }\end{array}$ & Authority & Exchange & $\begin{array}{l}\text { Solidarity, reciprocity, } \\
\text { collaboration }\end{array}$ \\
\hline & $\begin{array}{l}\text { Governance } \\
\text { principle }\end{array}$ & Control & Private ownership & $\begin{array}{l}\text { Ethical, participatory } \\
\text { self-governance }\end{array}$ \\
\hline & Value creation & Common goods & Material goods & $\begin{array}{l}\text { Common good, good living; } \\
\text { socio-cultural, economic and } \\
\text { environmental }\end{array}$ \\
\hline \multirow{4}{*}{ Operational } & Accountability & Inspection & Profits-shareholders & $\begin{array}{c}\text { Investment of } \\
\text { surplus-community }\end{array}$ \\
\hline & Justification & $\begin{array}{l}\text { Constitutional } \\
\text { rights }\end{array}$ & Consumer rights & $\begin{array}{l}\text { Human rights and } \\
\text { needs/capacities for good } \\
\text { living }\end{array}$ \\
\hline & Role of individual & Service beneficiary & Consumer & $\begin{array}{l}\text { Co-creator of value for the } \\
\text { community }\end{array}$ \\
\hline & Role of capital & Redistributive & Cumulative & Circular \\
\hline
\end{tabular}

In practice, there are subtle differences in the characteristics of social initiatives due to the polysemic nature of what we call the social economy. These diverse identities are reflected in terms such as: third sector, green economy, living well economy, economy for the common good, popular economy, community economy, jobs economy, circular economy, solidarity economy, inclusive economy, creative economy, fourth sector, and people-centered development [14] (p. 1). Each represents and relates to a specific socio-economic mode of organization, within a local, regional, national, and inter-regional geopolitical context identified by its actors. These different emphases represent a wide range of characteristics and approaches; among these, the United Nations Research Institute for Social Development [15] and the United Nations Inter-Agency Task Force on Social and Solidarity Economy advocate the Social and Solidarity Economy (SSE) as a model of alternative social development.

Table 2 presents some of the singularities of this alternative and innovative model compared with the Green Capitalism model that emerged from the dominant socio-economic model in the face of the current environmental crisis. 
Table 2. Social and Solidarity Economy versus Green Capitalism.

\begin{tabular}{|c|c|c|c|c|c|}
\hline Approaches & Criteria & World View & Time Frame & Problems to Resolve & $\begin{array}{l}\text { Locus for Action and Attitude } \\
\text { towards Globalisation }\end{array}$ \\
\hline $\begin{array}{l}\text { Alternative } \\
\text { Economic } \\
\text { Approaches }\end{array}$ & $\begin{array}{l}\text { Social and Solidarity } \\
\text { Economy }\end{array}$ & $\begin{array}{l}\text { Common good } \\
\text { (solidarity and } \\
\text { reciprocity) }\end{array}$ & $\begin{array}{l}\text { Short, medium } \\
\text { and long-term }\end{array}$ & $\begin{array}{c}\text { Prioritising profits over } \\
\text { people } \\
\text { Loss of ecological } \\
\text { diversity } \\
\text { Global warming } \\
\text { Increasing inequality } \\
\text { and lack of equal } \\
\text { opportunities }\end{array}$ & $\begin{array}{l}\text { Led by self-managed social } \\
\text { entrepreneurs and some local } \\
\text { governments } \\
\text { Against globalising capitalism }\end{array}$ \\
\hline \multicolumn{2}{|c|}{ Green Capitalism } & $\begin{array}{c}\text { Free market } \\
\text { (neo-liberal } \\
\text { economy) }\end{array}$ & Short-term & $\begin{array}{l}\text { Lack of economic } \\
\text { growth, market failures, } \\
\text { loss-making politics }\end{array}$ & $\begin{array}{l}\text { Led by national and international } \\
\text { institutions (IMF, World Bank, } \\
\text { etc.) } \\
\text { Tendency towards technologically } \\
\text { mediated globalisation }\end{array}$ \\
\hline
\end{tabular}

Source: Our adaptation based on Mochizuki and Yarime [16] (pp. 14-15).

The main characteristics of the SSE are as follows: teamwork, cooperation, self-management, inclusion, democracy, the connection of production to a specific geographical area, the creation of conditions for improving quality of life, and the sustainable local development of people and communities [17]. The double descriptor—social and solidarity—is used by Laville [18] after theorists such as Polanyi, Defourney, Hulgard, and Pestoff in Europe, and Coraggio, Gaiger, and Razeto in Latin America. These authors emphasize the attributes pertaining to both factors. While the meaning of social economy refers to an alternative economic model to organize the production, distribution, circulation, and consumption and their respective processes, solidarity economy is linked to the processes of democratization and the idea of equality with regard to the legality of people not only as economic subjects. It emphasizes the idea of redistribution not limited or reduced to the market economy and creation of reciprocity-based relations.

Even if this framework enjoys an increasing acceptation, its dissemination is not without controversy. Its main critics highlight its scarce originality, from a theoretic and methodological perspective, and the difficulties of implementing such a model in an economic context governed by the rules of capitalism [19-23]. However, despite the controversy, the SSE seems to consolidate.

Furthermore, the underlying economic model integrates economic, social, and environmental aims, implying a kind of development which shows not only social but also ecological concern, while still making room for economic-hence its affinity with sustainable development.

A wide range of organizations exists within the SSE framework [24] (pp. 16-17): cooperatives, social businesses, self-help groups, community organizations, informal worker associations, service NGOs, solidarity funding initiatives, etc. The majority are part of a network, for example: the European Network of Social Integration Enterprises, International Cooperative Alliance, and European Association of Service Providers for Persons with Disability.

All of these organizations display the following seven characteristics that define their mission values, at the same time differentiating them from other economic systems: (a) defense and promotion of human dignity; (b) constant creation and production of goods and services without neglecting ecological sustainability; (c) decision-making powers not linked to capital invested in the organization; (d) social justice through the fair distribution of income; (e) limited distribution of profits; (f) transparent and democratic participation and management; and (g) a high level of self-management [25] (pp. 58-59), [9]. They are guided by principles and practice of cooperation, solidarity, ethics, and democratic self-management.

Furthermore, it is worth noting that the SSE takes an axiological position similar to the ethical stance taken by sustainable development. Several strategies suggested by the Interagency Task Force for strengthening the SSE are thus pertinent to achieving the goals indicated in the UN's 2030 Agenda: (a) transition from an informal economy to decent work; (b) ecologizing the economy and society; and (c) local economic development, among others [26] (pp. 1,3, 6). What specifically do these two approaches have in common? We will deal with this question in the next section. 


\subsection{SSE and the 2030 Agenda Sustainable Development Goals (SDGs): Convergent Aims}

In 2015, the General Assembly of the UN unanimously passed the 2030 Agenda [27], a meaningful recognition on the part of the international community of the need to move towards "glocal" (both global and local) socio-ecological sustainability. This approval implies a significant commitment by member countries to meet, in the period 2016-2030, 17 SDGs, each one with corresponding and interrelating sub-aims directly related to fully exercising universal human rights. Sustainable development, an approach going back to the last century, is now taking hold in the international community. It was initially a social innovation movement, among other alternatives, much like the SSE. It is not surprising, then, to find the aims of both converging, as we shall see.

Cooperatives, social enterprises, and fair trade businesses, all within the SSE, are playing a key role in promoting economic growth that is sustained and inclusive [28-30]. Cooperatives in particular are able to facilitate access to funding, materials, technologies, support services, and markets, thereby increasing the capacity of producers to negotiate supply prices of primary materials. This is in line with SDG 8 (decent work and economic growth) [6] (p. 19), of which one of the main challenges lies in reducing the inequalities of power and knowledge that exist in goods and labor markets. Certain types of cooperative can also be beneficial to those working informally who want to regularize their economic activity with an initial, small capital investment, fostering contributive justice and social justice among economic actors.

Its increasing presence in the economic sector implies a greater acceptance of the SSE's values and principles. For example, in the European Union (EU) there are around 160,000 registered cooperatives, in the ownership of 123 million citizens (one third of the population). They provide decent employment for 5.4 million people and, as shown in Table 3, have been able to grow their market share in different countries and sectors [31].

Table 3. Productive sectors in the European Union/Sustainable Development Goals (EU/SSE).

\begin{tabular}{ll}
\hline Productive Sector & Countries \\
\hline Agriculture & $83 \%$ in The Netherlands, 79\% in Finland, 55\% in Italy, and $50 \%$ in France. \\
Forestry & $60 \%$ in Sweden and 31\% in Finland. \\
Financial services & $50 \%$ in France, 37\% in Cyprus, 35\% in Finland, 31\% in Austria and 21\% in Germany. \\
Retail & $36 \%$ in Finland and $20 \%$ in Sweden. \\
Pharmacy and health & $21 \%$ in Spain and $18 \%$ in Belgium. \\
\hline
\end{tabular}

Source: European Commission [31].

From this standpoint, the link with SDGs 1 (no poverty) and 10 (reduced inequalities) is obvious [6] (pp. 15-21). The SSE contributes to these goals in creating a productive network, improving access rights to economic resources, facilitating access to social services, offering support and, given that not discriminating on gender grounds is among its principles, economically empowering women. All these aims are also related to other SDGs, such as number 8 mentioned above, in the creation of decent employment, or number 5 (gender equality) [6] (p. 18).

Moreover, in terms of ecologizing the economy and society, the SSE is committed to limiting the increase of negative environmental impact as a priority-even at the cost of slowing growth and economic development. SSE organizations tend to produce a smaller carbon footprint, due not only to their environmental objectives but also to the nature of their systems of production and exchange [26] (p. 5). In the social and solidarity economic model, environmental management is carried out in a way that recognizes and accepts both the collective responsibility for its effects and the scarcity directly assist the fulfilment of SDGs 12 (responsible consumption and production) [6] (p. 22) and 13 (climate action) [6] (p. 22) and, indirectly, SDGs 14 (life below water) [6] (p. 23) and 15 (life on land) [6] (pp. 24-25).

Finally, in relation to local economic development, it is worth highlighting that the SSE presents a holistic vision of the economic development of communities, promoting the reactivation and 
regeneration of social, financial, and intellectual capital locally. Its attention is focused on responding to, and covering, community needs and rights not taken care of in a satisfactory or equitable way by either private or public sector organizations [8]. The SSE possesses, then, the know-how to create an eco-entrepreneurial culture through local self-managed and participatory governance, generating social cohesion and trust. As such, it contributes directly to SDG 11 (sustainable cities and communities) [6] (pp. 21-22), as well as indirectly to the remaining aims of the 2030 Agenda.

Evidence of its effective social engagement is the large number of governments starting to recognize the role of SSE in job creation after the financial crisis, and the support offered by the EU [11,32]. SSE organizations are also helping to counteract the growth of precarious employment and the inability of the traditional sectors to fulfil their role in absorbing workforce surplus in rural and post-industrial areas, for example [33] (p. 4). Although the role of the SSE in the development of infrastructure is centered mainly on social infrastructure and energy, it also has a valuable role to play in the development of economic infrastructures.

This similarity of aims demonstrates that the SSE has in the 2030 Agenda something solid on which to build its own identity, benefiting from the international backing and instruments arbitrated by the UN in order to reach towards achieving the SDGs. Among these are the recommendations to improve the quality of education, a strategy of proven efficiency consistent with the challenge posed by the notion of sustainability.

\section{Education in the Context of a SSE Aiming to Achieve the SDGs}

Various environmental educational denominations contribute both to achieving the SDGs and to furthering the SSE. However, it is education for sustainable development that is generally recognized and is the approach backed specifically by UNESCO [34] for dealing with current educational and training needs.

The body of theory that exists today has its origins in the environmental education of the 1970s. It is supported by an extensive literature that covers its conceptual and axiological foundations [35-40] and tends towards addressing practical issues around its implementation [41-45]. It is an innovative educational approach that aims for a consciousness of belonging to a life community, creating an identity at once local and global and strengthening one's perception of interdependence and eco-dependence [46].

This is the educational approach, the characteristics of which are described in more detail above, that befits an SSE aiming towards achieving the SDGs. Bearing in mind the strategic vision of the SSE, its mission is accomplished through educating communities for socio-economic growth. This represents a clear commitment towards adult education focused on social entrepreneurship. Note that placing the focus of education in adult teaching does not imply at all that only this population group needs teaching in order to contribute to the SDGs. It is a necessity that requires urgent attention in all the modalities and levels of education [7]. In this specific case, due to the own objectives of the ESS, the adults are the explicit addressees of the teaching programmes because they are the active subjects of the economic relations.

Meredith and Quiroz-Niño [47] (Chapter 7, pp. 23-25) highlight four main areas within social entrepreneurship adult education, which have been adapted for this article: (a) individual and collective transformation; (b) eco-community well-being creation; (c) social innovation and economic sustainability; and (d) care for the environment. These four areas are complementary and must be integrated holistically, rather than siloed. The latter would inevitably mean distorting, limiting, and reducing relational capacity and the complexity of human reality in community contexts.

We consider that in each of these four areas, the educational processes have to be approached from four perspectives: ontological (being well), functional (living well), operational (doing well), and ecological (caring well). 


\subsection{Ontological Perspective (Being Well)}

The ontological perspective on a SSE educational model geared towards fulfilling the SDGs first requires an exercise in resignifying the phenomena and processes with which humans interact, in order to situate them in the field of eco-living. Critical thinking is required, and an ability to question dominant economic models and personal and external behaviors, the effects of which contribute to the widespread socio-ecological crisis. From this point of view, it is the role of education to develop people's capacity to gain awareness of the close links between the economy and the more immediate-physical, ecological, spiritual and social-environment, and, therefore, to take on the responsibility, personal and collective, for the effects of the former on the latter.

This awareness raising is necessary for the extent to which, as Pigem [48] (p. 86) rightly asserts, the economy has become an "egonomy"; it is centered on the self and self-development. From the perspective of sustainability and the SDGs, the situation requires a Copernican revolution. The transformation that the SSE is calling for requires competencies for developing and exerting ethical and facilitative leadership. This means being able to determine a clear and explicit ethical position, once the need for urgent change in the face of dominant reductionist views and logic in relation to human existence is understood [49]. The capabilities and capacities needed for this (some of which are shown in Table 3) become the object of education.

This new human-nature-economy correlation calls for a new and unambiguous relationship between what one is and what one is working for-an ontological necessity, for it implies a coherence between what one believes, says, and does. It demands a process of reassigning meaning to one's life and mission, based on ethical frameworks and standards of living and working that include-as demanded by SDG 8 [6] (pp. 19-20)—fair and equitable working conditions. It relates also to the right of every person to feel that he/she is doing a valuable job and is valued for doing it, contributing thereby to SDG 3 (good health and well-being) [6] (pp. 16-17).

Moreover, because of the interdependent relationship we have with others, individual transformation also includes awareness of the meaning of quality of life and work for collective well-being and empowerment, and for community development. The psycho-affective processes arising from this individual transformation are key for confronting injustices that alienate or marginalize the person when their legitimate rights and needs are threatened, and are essential for meeting the goals of the 2030 Agenda.

Individual transformation consistent with the principles and values of sustainability requires a profound change in the way the person sees his/her eco-existence and commitment to nature and the environment [50]. The capabilities and capacities required for what it has been expressed before are shown in Table 4, and thus become the object of education.

Table 4. Ontological perspective (being well): areas and capacities for training.

\begin{tabular}{|c|c|c|c|c|}
\hline \multicolumn{5}{|c|}{ Capacity for... } \\
\hline Field & Cognitive & $\begin{array}{l}\text { Understand the } \\
\text { assumptions and } \\
\text { inferences on which the } \\
\text { social, political, cultural } \\
\text { and ecological imaginary } \\
\text { of the society and } \\
\text { community is based }\end{array}$ & $\begin{array}{l}\text { Question the values and } \\
\text { principles that sustain } \\
\text { different economic } \\
\text { models and their } \\
\text { legitimacy in the name } \\
\text { of the 'common good' }\end{array}$ & $\begin{array}{l}\text { Analyze in depth the complex } \\
\text { nature of the sustainable } \\
\text { development goals and critique } \\
\text { every possible interpretation }\end{array}$ \\
\hline
\end{tabular}


Table 4. Cont.

\begin{tabular}{ccccc}
\hline & Capacity for... & Apply effective techniques \\
for combating \\
monoculture which \\
Field
\end{tabular}

\subsection{Functional Perspective (Living Well)}

The functional perspective of the SSE refers to the capacities of citizens engaging directly with daily behaviors, focused on the good living of the community. It is a priority to focus attention on the education and development of the capabilities of relating to others and creating mutual trust. Both of these have to grow alongside each other as two sides of a coin with equal emphasis. Some of these capabilities are set out in Table 5 with no suggestion that this list is exhaustive.

Table 5. Functional perspective (living well): areas and capacities for training.

\begin{tabular}{|c|c|c|c|c|}
\hline \multicolumn{5}{|c|}{ Capacity for... } \\
\hline \multirow{4}{*}{ Field } & Cognitive & $\begin{array}{l}\text { Identify the vital elements } \\
\text { making up the ecosystem in } \\
\text { which the community lies }\end{array}$ & $\begin{array}{l}\text { Understand the impact of } \\
\text { different forms of intervention } \\
\text { for regenerating and } \\
\text { recuperating community } \\
\text { resources in a sustainable way }\end{array}$ & $\begin{array}{l}\text { Identify and analyse the } \\
\text { external and internal } \\
\text { factors that make } \\
\text { community interventions } \\
\text { successful or not }\end{array}$ \\
\hline & Psycho-affective & $\begin{array}{c}\text { Develop activities that } \\
\text { generate trust and empower } \\
\text { people to take on } \\
\text { sustainable, } \\
\text { intergenerational } \\
\text { community initiatives }\end{array}$ & $\begin{array}{l}\text { Promote political identity and } \\
\text { a sense of belonging to a } \\
\text { community, through actual } \\
\text { and/or virtual presence }\end{array}$ & $\begin{array}{c}\text { Deconstruct } \\
\text { socio-economic behaviours } \\
\text { in order to understand the } \\
\text { motivations underpinning } \\
\text { collective commitment }\end{array}$ \\
\hline & Operational & $\begin{array}{c}\text { Apply participatory } \\
\text { methods and dynamics to } \\
\text { define indicators that value } \\
\text { the community's social } \\
\text { capital }\end{array}$ & $\begin{array}{l}\text { Facilitate and design } \\
\text { participatory budgets to } \\
\text { achieve equity and } \\
\text { socio-economic equality } \\
\text { among community members }\end{array}$ & $\begin{array}{c}\text { Apply strategies, } \\
\text { techniques, and dynamics } \\
\text { that counteract } \\
\text { unsustainable community } \\
\text { practices, both traditional } \\
\text { and modern }\end{array}$ \\
\hline & Axiological & $\begin{array}{l}\text { Foster collective living based } \\
\text { on reciprocity and solidarity } \\
\text { that benefits individual and } \\
\text { collective interests as much } \\
\text { as possible }\end{array}$ & $\begin{array}{l}\text { Account for tangible and } \\
\text { intangible results of } \\
\text { paperwork carried out on the } \\
\text { community's behalf }\end{array}$ & $\begin{array}{l}\text { Identify past, present, and } \\
\text { future community values, } \\
\text { and how these have } \\
\text { been/can be put into } \\
\text { practice in the community } \\
\text { to guarantee good living }\end{array}$ \\
\hline
\end{tabular}

Source: Original work.

These are cornerstone values such as direct democracy, solidarity, trust, and reciprocity, which require a strong political and community commitment, alongside a view of citizens as collective and actively participative agents. The model underlying community organization is based on an entrepreneurial culture requiring capabilities and capacities enabling autonomy, innovative initiative, openness to risk and failure, and the high level of resilience that social capital and cohesion can create [51]. 
Part of community well-being is the involvement of representatives from all interested groups in the governance and participatory management model, and the development of social capital, rendering it an axiological category of its own. This is so that everyone develops a sense of belonging and is open to addressing challenges and finding solutions together. An open and shared dialogue between the community and the institutions within it is essential, in order to assess the social, cultural, environmental, and economic impact of the community's vision about growth and development. Equally necessary is collaborative decision making, on strategic as well as operational issues, for example, on participatory budgeting. All this contributes to SDG 16 (peace, justice, and strong institutions) [6] (pp. 25-26).

Such action leads to, or reinforces, learning about the competencies for democracy considered key to the type of citizenship required for sustainable development [52,53]. There is also greater potential for collaborative work of an inter-generational and intra-generational nature, extending the family nucleus-all within the framework of lifelong learning.

On the other hand, community well-being includes the personal fulfilment of all the members of the community, to which employment contributes significantly. In turn, this employment is a factor of major importance as a facilitator of active community participation in the resolution of community problems. In the SSE framework, this contribution values in terms of the capacity to develop relationships to strengthen the social, intellectual, and cultural capital of the community. This is true even in autonomous work or self-employment. This relates directly to SDG 3 (good health and well-being) [6] (pp. 16-17).

\subsection{Operational Perspective (Doing Well)}

The operational perspective pays attention to the capacities that the adult needs to achieve economic sustainability through social innovation, and the decent work deriving from that. In this framework, social innovation is a creative and productive process alongside psycho-social dynamics, constantly generating ideas which are transformed into services and products, with the main aim of bringing about a positive change, as well as providing income and surplus. Thus, the positive changes contribute towards well-being. These processes allow for value creation within communities. To achieve and maintain economic, social, and environmental sustainability is one of the main aspirations of SSE organizations [24]. The big challenge this represents affords education a critical role in educating and training. Some of these capabilities and capacities are shown in Table 6.

Table 6. Operational perspective (doing well): areas and capacities for training.

\begin{tabular}{|c|c|c|c|c|}
\hline \multicolumn{5}{|c|}{ Capacity for... } \\
\hline \multirow{3}{*}{ Field } & Cognitive & $\begin{array}{l}\text { Understand innovative processes } \\
\text { in the organisation and } \\
\text { management of social enterprises }\end{array}$ & $\begin{array}{l}\text { Know and understand what } \\
\text { makes a culture of enterprise } \\
\text { and innovation create } \\
\text { sustainability in } \\
\text { social/community initiatives }\end{array}$ & $\begin{array}{l}\text { Know the best way of } \\
\text { diversifying the community's } \\
\text { labour, production, and social } \\
\text { markets, taking fair } \\
\text { distribution of work into } \\
\text { account }\end{array}$ \\
\hline & Psycho-affective & $\begin{array}{l}\text { Explore perceptions of a problem } \\
\text { in order to implement certain } \\
\text { solutions and required changes } \\
\text { alongside the people affected }\end{array}$ & $\begin{array}{l}\text { Assess and determine the best } \\
\text { options for SSE organisations' } \\
\text { reinvestment of surplus in the } \\
\text { organisation and in my } \\
\text { community }\end{array}$ & $\begin{array}{c}\text { Develop processes for the } \\
\text { inclusion of differently-abled } \\
\text { people, migrants, and refugees }\end{array}$ \\
\hline & Operational & $\begin{array}{l}\text { Apply social innovation } \\
\text { techniques and processes to create } \\
\text { sustainable products and/or } \\
\text { services within and outside my } \\
\text { community }\end{array}$ & $\begin{array}{l}\text { Design effective campaigns for } \\
\text { communicating the benefits of } \\
\text { the products, services, and ideas } \\
\text { offered by my social enterprise } \\
\text { and/or movement }\end{array}$ & $\begin{array}{l}\text { Carry out social audits of } \\
\text { eco-community enterprises } \\
\text { and initiatives }\end{array}$ \\
\hline
\end{tabular}


A significant characteristic of organizations within the SSE framework is a full awareness that with greater diversification and income generation come greater responsibility for contributing to the development and positive transformation of their own communities-good economic performance leaves them with more responsibility when making decisions linked to eco-community development. As such, it is vital that social enterprises know not only the economic but also the social and environmental impacts of their productive activity, and behave accordingly.

For example, in the case of fair trade, the effects on the community go beyond the process of production, access to new markets, and exchange, into the field of decent work, fair pay, and working conditions in the countries where the primary materials originated. The price of services and products may be higher than the market average since good practice in relation to fair working conditions and care for the environment are presumed. Social enterprises consider these costs (in contrast to other types of businesses which ignore them), thus avoiding their translation into civil society in the form of high levels of poverty, socio-economic discrimination, and environmental destruction [54].

In this context, a key aspect is the importance given to the traceability of primary materials used in the production of goods and services. Knowledge and understanding of the circumstances surrounding goods and suppliers are important when it comes to buying and consumption. All these practices give SSE organizations a value intrinsic to their modus operandi and set them apart as active agents for sustainable development in the SDG framework.

\subsection{Ecological Perspective (Caring Well)}

It is increasingly evident that problems in natural resource management, driven by other serious socio-ecological problems, are growing more and more [55,56]. SSE organizations are committed to using ecologically sensitive technologies in their productive processes. Two significant strategies stand out. First, the certification of products made using organic, biodegradable, or recycled materials (e.g., Fairtrade, Rainforest Alliance), which acts as an effective tool for evidencing the commitment of social enterprises to reducing or eliminating the negative externalities impact of their activities on the environment [57]. Second, the revival of ancient practices promoted by organizations with environmental protection and the constant improvement of resource management.

Environmental protection implies, among other behaviors, the following: the responsible use of natural resources; the recognition and reduction of the use of contaminants in productive processes; the recycling of waste; and the treatment of waste in more efficient ways than conventional technologies allow. As in the previous areas for action, social entrepreneurs require certain capacities for this, as shown in Table 7. Education has, once again, an important function.

Table 7. Ecological perspective (caring well): areas and capacities for training.

\begin{tabular}{|c|c|c|c|c|}
\hline \multicolumn{5}{|c|}{ Capacity for... } \\
\hline \multirow[b]{3}{*}{ Field } & Cognitive & $\begin{array}{l}\text { Understand, analyse, and } \\
\text { identify interactions within a } \\
\text { socio-ecological system (SES) }\end{array}$ & $\begin{array}{l}\text { Understand the community's } \\
\text { capacity for SSE resilience } \\
\text { through innovating and } \\
\text { regenerating }\end{array}$ & $\begin{array}{l}\text { Analyse effective practices } \\
\text { for reducing the } \\
\text { environmental footprint of } \\
\text { one's enterprise activities }\end{array}$ \\
\hline & Psycho-affective & $\begin{array}{l}\text { Understand how experiencing } \\
\text { natural disasters wrought by } \\
\text { climate change affect physical } \\
\text { and mental health }\end{array}$ & $\begin{array}{c}\text { Promote cross-cutting gender } \\
\text { equality and equal } \\
\text { opportunities in the short, } \\
\text { medium, and long term }\end{array}$ & $\begin{array}{l}\text { Promote citizens' } \\
\text { participation for restoring } \\
\text { ecological habitats in the } \\
\text { community }\end{array}$ \\
\hline & Operational & $\begin{array}{c}\text { Foster ecological behaviours } \\
\text { that have a positive and } \\
\text { lasting impact on the } \\
\text { surrounding area }\end{array}$ & $\begin{array}{l}\text { Revive traditional modes of } \\
\text { production (textiles, organic } \\
\text { products) that respect the } \\
\text { environment and create decent } \\
\text { work }\end{array}$ & $\begin{array}{c}\text { Start time-banks, } \\
\text { foodbanks, tool libraries, } \\
\text { community fridges }\end{array}$ \\
\hline
\end{tabular}




\section{Key for Change: Including the Principles and Values of Sustainability in the Educational and Training Projects}

The capacities and capacities described above are training needs that must be addressed by the adult education within the framework of SSE. Each of these contributes to what has been called key competencies for sustainability, as shown in Table 8, which help to achieve the SDGs when employed in community development contexts.

Table 8. Key competencies for sustainability) [42] (p. 10).

\begin{tabular}{|c|c|}
\hline Competencies & Working Definition \\
\hline Systems thinking competency & $\begin{array}{l}\text { the abilities to recognise and understand relationships; to analyse } \\
\text { complex systems; to think of how systems are embedded within } \\
\text { different domains and different scales; and to deal with uncertainty. }\end{array}$ \\
\hline Anticipatory competency & $\begin{array}{l}\text { the abilities to understand and evaluate multiple futures-possible, } \\
\text { probable and desirable; to create one's own visions for the future; to } \\
\text { apply the precautionary principle; to assess the consequences of actions; } \\
\text { and/or deal with risks and changes. }\end{array}$ \\
\hline Normative competency & $\begin{array}{l}\text { the abilities to understand and reflect on the norms and values that } \\
\text { underline one's actions and to (negotiate) ensure the survival of } \\
\text { sustainability values, principles, and to negotiate goals, and targets, in a } \\
\text { context of conflicts of interests and trade-offs, uncertain knowledge, and } \\
\text { contradiction. }\end{array}$ \\
\hline Strategic competency & $\begin{array}{l}\text { the abilities to collectively develop and implement innovative actions } \\
\text { that further sustainability at the local level and further afield. }\end{array}$ \\
\hline Collaboration competency & $\begin{array}{l}\text { the abilities to learn from others; to understand and respect the needs, } \\
\text { perspectives, and actions of others (empathy); to understand, relate to, } \\
\text { and become sensitive to others (empathic leadership); to deal with } \\
\text { conflicts in a group; and to facilitate collaborative and participatory } \\
\text { problem solving. }\end{array}$ \\
\hline Critical thinking competency & $\begin{array}{l}\text { the ability to question norms, practices and opinions; to reflect on own } \\
\text { one's values, perceptions, and action, and to take a position in the } \\
\text { sustainability discourse. }\end{array}$ \\
\hline Self-awareness competency & $\begin{array}{l}\text { the ability to reflect on one's own role in the local community and } \\
\text { (global) society; to continually be motivated to take action and to deal } \\
\text { with one's feelings and desires. }\end{array}$ \\
\hline $\begin{array}{l}\text { Integrated problem-solving } \\
\text { competency }\end{array}$ & $\begin{array}{l}\text { the overarching ability to apply different problem-solving frameworks } \\
\text { to complex sustainability problems and develop viable, inclusive, and } \\
\text { equitable solutions and options that promote sustainable development, } \\
\text { integrating the above-mentioned competences. }\end{array}$ \\
\hline
\end{tabular}

Training in sustainability competencies is multifaceted; it is no easy task to define each of these facets concretely in teaching practice. Firstly, the interacting components that make up the competency must be defined. Then, we must recognize the capacities that will create these components in practice. Finally, these capacities must be associated with indicators that allow us to infer the existence of corresponding capacities [58] (p. 68).

This is a multidimensional process that tackles technical and logistical questions directly related to professional practices, but also the fundamental concepts and values of sustainability [59]. It also takes into account, as basis, the four great pillars of education described in the Delors Report [60]. It demands an active commitment on the part of teachers, educators of adults, that is demonstrated not only in the design of teaching activities and projects but also in their implementation [61]. In short, teaching practice as a whole must be imbued with the principles and values of sustainable development.

As an example, Table 9 shows a basic design matrix for training aimed at acquiring one of the key competencies for sustainability as outlined by UNESCO [42], the normative competency. 
Pedagogic action lies within one of the areas for action identified (as mentioned above) by Meredith and Quiroz-Niño, et al. [48] for adult training in the SSE framework: social innovation and economic sustainability.

Table 9. Normative competency: performance indicators.

\begin{tabular}{|c|c|c|c|}
\hline \multicolumn{4}{|c|}{$\begin{array}{l}\text { Normative Competency } \\
\text { the Competence to Understand the World Economy Systems and Reflect on the Norms and Values that } \\
\text { Underpin a Sustainable Development through SSE Organisations, e.g., Social and Community } \\
\text { Enterprises, Cooperatives, Time-Banks, etc. }\end{array}$} \\
\hline \multirow{2}{*}{ Capacities } & \multicolumn{3}{|c|}{ Key Indicators of Achievement and Commitment } \\
\hline & Basic & Intermediate & Advanced \\
\hline $\begin{array}{l}\text { Understand the values } \\
\text { and norms that regulate } \\
\text { the prevailing economic } \\
\text { systems: private, public, } \\
\text { and social }\end{array}$ & $\begin{array}{l}\text { Explain the terms and } \\
\text { concepts related to the } \\
\text { three economic systems } \\
\text { and their differences }\end{array}$ & $\begin{array}{l}\text { Critically evaluate the } \\
\text { scale, reach, impact, and } \\
\text { sustainability of each }\end{array}$ & $\begin{array}{l}\text { Discuss the historical } \\
\text { and ideological } \\
\text { precedents of each } \\
\text { system and its relation to } \\
\text { sustainable development }\end{array}$ \\
\hline $\begin{array}{l}\text { Demonstrate the } \\
\text { relationship between SSE } \\
\text { values with a just, } \\
\text { equitable society }\end{array}$ & $\begin{array}{l}\text { Identify the presence of } \\
\text { SSE values (reciprocity, } \\
\text { participation, } \\
\text { redistribution, and } \\
\text { subsidiarity) in } \\
\text { social/community } \\
\text { enterprises }\end{array}$ & $\begin{array}{l}\text { Show evidence of how } \\
\text { governance of social and } \\
\text { community enterprises } \\
\text { influences the good } \\
\text { living of its workers and } \\
\text { its community }\end{array}$ & $\begin{array}{l}\text { Take on the } \\
\text { responsibility of } \\
\text { defending SSE values } \\
\text { across community } \\
\text { initiatives }\end{array}$ \\
\hline $\begin{array}{l}\text { Link the SSE to the } \\
\text { promotion of decent } \\
\text { work }\end{array}$ & $\begin{array}{l}\text { Describe in a clear and } \\
\text { concise way the elements } \\
\text { that comprise decent } \\
\text { work in SSE } \\
\text { organisations }\end{array}$ & $\begin{array}{l}\text { Analyse and unpick } \\
\text { what decent work is } \\
\text { based on its defining } \\
\text { characteristics }\end{array}$ & $\begin{array}{l}\text { Evaluate and denounce } \\
\text { any action that infringes } \\
\text { on decent work }\end{array}$ \\
\hline
\end{tabular}

Source: Original work.

The normative competency is firmly values-based. Ethics play a central role in the training processes for acquiring this competency; processes that must be inspired by values, principles, and rules that make up the essence of sustainability. In our case, the key capacities that integrate this normative competency must allow: (a) an understanding of the axiological models underlying economic systems; (b) evaluation of these models in terms of social equity and justice; and (c) concrete links to be made between these models and the creation of decent work. In this table, the performance indicators gathered, at different points of completion, are important objectives to integrate into training projects aimed at training adults in the SSE framework.

\section{Conclusions}

This article has allowed us to explore and outline the potential convergences between the SSE model and the 2030 Agenda approved by the UN that sets out the Sustainable Development Goals to be met by the international community in the period 2016-2030. The commonality of their respective values permits joint and complementary strategic action and understanding, channeling these possible synergies towards achieving the SDGs in promoting fairer and more inclusive societies. Not merely a possible option, this is surely an urgent moral and ethical necessity requiring educational intervention to act with assertion, resilience, and commitment to the past, present, and future of humanity and the planet.

The SSE, by its nature and its values, is called upon to create learning and teaching processes linked to community development projects in the various instances of social, work, and cultural interaction that exist in ecosystems to cover fundamental needs and satisfy human rights. This makes possible the transformation and qualitative change towards sustainable and inclusive well-being, both 
personal and collective. The SSE cultivates a mentality, disposition, and attitude that corresponds to an enterprising culture which, among other things, reinforces through decent work and collaborative community initiatives the feeling (interdependence and eco-dependence) of belonging to a local and a global community.

The educational proposal presented in this paper keeps a tight coherence with the great pillars that the Derlors Report points as essential basis of a quality education: Learning to Be, Learning to Do, Learning to Live together, and Learning to Know [60]. The four dimensions that in this paper have been called ontological (being well), functional (living well), operational (doing well), and ecological (caring well), provide in their operational implementation a wide response to the mentioned pillars. Furthermore, it can be said that they reinforce the pillars in the aspects related to living well and caring well, which are essential in the framework of sustainability.

This article has been able to detail more precisely how, in the SSE framework, education should facilitate the acquisition of a series of competencies, and capacities at a cognitive, psycho-affective, operational, and axiological level, within a community ecosystem. Education centers, community centers, businesses, health centers, production cooperatives, NGOs, parks, urban gardens, and leisure spaces could all operate as training spaces in which different social educators act as facilitators, social entrepreneurs, and community leaders.

Adult education and training becomes the strategy to maximize the ability of adults to relate and participate both inside and outside their communities. Educators of adults have a decisive role to play for innovating and leading the sustainabilisation of training programs in such a way that the principles and values of the 2030 Agenda and its 17 SDGs form synergies with those that drive the SSE, in order to influence and impact on situations of inequality, social injustice, abuses of power, and any violation of rights taking place around them. It is a task not without obstacles. As well as requiring institutional strategies to make it possible, educators must be actively committed and receive technical training to bring the necessary innovation to their teaching practice. The limitations, obstacles, and challenges that will have to be faced in this process have not been studied in this paper. The approach of SSE has still a too short trajectory and, furthermore, only 2 years have passed since the implementation of Agenda 2030. Empirical studies are required in order to assess the contribution of Agenda 2030 to adult education in the framework of SSE.

This paper has placed the attention focus in the field of adult education, and in the acquisition of competencies for sustainable development in the framework of the teaching-learning processes for socio-economic development, entrepreneurship, decent work, and self-employment. The topic, however, is not exhausted. The Agenda 2030 lays out a great challenge at all levels, sectors, and education modalities. In all of them, the teaching of competences for sustainability is an unavoidable, complex, and polyhedral task.

Acknowledgments: The authors would like to thank the financial support from the Universidad Nacional de Educación a Distancia, UNED (Spain). Original Spanish version translated by Charles Hanks.

Author Contributions: Both authors were involved in the development of this paper. Catalina Quiroz-Niño is the lead writer of the text, based on her doctoral research. María Angeles Murga-Menoyo has contributed to the content, reviewed the text and provided comments.

Conflicts of Interest: The authors declare no conflict of interest.

\section{References}

1. Mindt, L.; Rieckmann, M. Desarrollo de las competencias para el emprendimiento orientado a la sostenibilidad en la educación superior: Una revisión bibliográfica de los métodos de enseñanza y aprendizaje. Teoría de la Educación Revista Interuniversitaria 2017, 29, 129-159. [CrossRef]

2. Polanyi, K. The Great Transformation: The Political and Economic Origins of Our Time; Beacon Press: Boston, MA, USA, 1957.

3. Max-Neef, M. La Economía Desenmascarada. Del Poder y la codicia a la Compasión y el Bien Común; Icaria: Barcelona, Spain, 2011. 
4. UN. Aplicar la Agenda 2030 a Través de la Economía Social y Solidaria. Grupo de Trabajo Interinstitucional de las Naciones Unidas sobre Economía Social y Solidaria. Available online: http:/ / unsse.org/wp-content/ uploads/2014/08/ES_Final_Position_Paper_SSE_SDGs_FAO_Geneva_es.pdf (accessed on 2 June 2017).

5. UN. Social and Solidarity Economy for the SDGs: Spotlight on the Social Economy in Seoul; United Nations Research Institute for Social Development (UNRISD): Geneva, Switzerland, 2017.

6. UN. Transforming Our World: The 2030 Agenda for Sustainable Development. Resolution Adopted by the General Assembly on 25 September 2015A/RES/70/1. 2015. Available online: http://www.un.org/ga/ search/view_doc.asp?symbol=A/RES/70/1\&Lang=E_ (accessed on 17 June 2017).

7. Murga-Menoyo, M.A. Learning for a Sustainable Economy: Teaching of Green Competencies in the University. Sustainability 2014, 6, 2974-2992. [CrossRef]

8. UN. World Commission on Environment and Development. Available online: http:/ /www.un-documents. net/our-common-future.pdf (accessed on 30 August 2017).

9. Defourny, J.; Hulgård, L.; Pestoff, V. Social Enterprise and the Third Sector; Routledge: London, UK, 2014.

10. Utting, P. Social and Solidarity Economy beyond the Fringe; United Nations Research Institute for Social Development (UNRISD): Geneva, Switzerland, 2015.

11. OECD/EU. Boosting Social Enterprise Development: Good Practice Compendium; OECD Publishing: Paris, France, 2017; Available online: http:/ /dx.doi.org/10.1787/9789264268500-en (accessed on 31 July 2017).

12. Pearce, J. Social Enterprise in Anytown; Calouste Gulbenkian Foundation: London, UK, 2003; p. 25.

13. Dash, A. Toward an epistemological foundation for social and solidarity economy. In Potential and Limits of the Social and Solidarity Economy; United Nations Research Institute for Social Development (UNRISD): Geneva, Switzerland, 2014.

14. UN. La Economía Social y Solidaria y el Reto del Desarrollo Sostenible; Interagency Task Force Social and Solidarity Economy (ITFSSE): Geneva, Switzerland, 2016; p. 1.

15. Utting, P. Social and Solidarity Economy: A Pathway to Socially Sustainable Development? United Nations Research Institute for Social Development (UNRISD): Geneva, Switzerland, 2013.

16. Mochizuki, Y.; Yarime, M. Education for Sustainable Development and Systainability Science. In Routledge Handbook of Higher Education for Sustainable Development; Barth, M., Michelsen, G., Rieckmann, M., Thomas, I., Eds.; Routledge: Oxon, UK, 2016; pp. 14-15.

17. Aguilar, H.; Eduardo, E. Economía Solidaria y territorio: Complejizando la propuesta de análisis territorial de Coraggio. Revista Polis 2016, 45. Available online: http://polis.revues.org/12033 (accessed on 27 October 2017).

18. Laville, J.-L. The Social and Solidarity Economy. In Social Enterprise and the Third Sector. Changing European Landscapes in a Comparative Perspective; Defourny, J., Hulgård, L., Pestoff, V., Eds.; Routledge: Oxon, UK, 2014; pp. 102-113.

19. Pérez de Mendiguren, J.C.; Etxezarreta, E. Los debates en torno a la economía social y solidaria. Boletín de Recursos de Información 2015, 42, 12.

20. Pérez de Mendiguren Castresana, J.C. Social enterprise in the development agenda. Opening a new road map or just a new vehicle to travel the same route? Soc. Enterp. J. 2013, 9, 247-268. [CrossRef]

21. Heras-Saizarbitoria, I. The ties that bind? Exploring the basic principles of worker-owned organizations in practice. Organization 2014, 21, 645-665. [CrossRef]

22. Guridi, L.; Pérez de Mendiguren, J.C.; Iametti, A.; Deux, M.V.; Vázquez, G.; Uribe, A. Experiencias de Economía Social y Solidaria: Compartiendo estrategias y aprendizajes. Papeles de Economía Solidaria 2011, 2 , $1-77$.

23. García, J. La Economía Solidaria en el Estado Español. In Crisis Capitalista y Economía Solidaria. Una Economía Que Emerge Como Economía Real; Laville, J.L., García, J., Eds.; Icaria Antrazyt: Barcelona, Spain, 2009.

24. Ridley-Duff, R.; Bull, M. Understanding Social Enterprise. Theory and Practice, 2nd ed.; Sage: London, UK, 2016; pp. 16-17.

25. Felber, Ch. La Economía del Bien Común; Grupo Planeta: Deusto, España, 2012; pp. 58-59.

26. UN. La Economía Social y Solidaria y el Reto del Desarrollo Sostenible. Available online: http://unsse.org/ wp-content/uploads/2014/08/Position-Paper_TFSSE_Esp1.pdf (accessed on 30 June 2017).

27. UN Adopts New Global Goals, Charting Sustainable Development for People and Planet by 2030. Available online: http:/ / www.un.org/apps/news/story.asp?NewsID=51968\#.WckJeVtSzIV (accessed on 15 July 2017). 
28. International Labour Organization. Cooperatives and the Sustainable Development Goals: A Contribution to the Post-2015 Development Debate. A Brief. 2014. Available online: http://www.ilo.org/empent/ Publications/WCMS_240640/lang--en/index.htm (accessed on 18 November 2017).

29. International Cooperative Alliance. Blueprint for a Co-Operative Decade. 2013. Available online: http:/ / ica. coop/en/media/library/member-publication/blueprint-co-operative-decade-february-2013 (accessed on 18 November 2017).

30. UNGA. The Future We Want. Resolution of the United Nations General Assembly Adopted on 27 July 2012. Available online: http:/ / daccess-dds-ny.un.org/doc/UNDOC/GEN/N11/476/10/PDF/N1147610.pdf? OpenElement (accessed on 25 October 2017).

31. European Commission. Available online: http://ec.europa.eu/growth/sectors/social-economy/ cooperatives_en (accessed on 30 June 2017).

32. European Commission. Statement from the European Commission by Astrid Schomaker, Directorate-General for Environment. Available online: http:/ / ec.europa.eu/DocsRoom/documents/18141/attachments/1/ translations (accessed on 30 June 2017).

33. NNUU. Aplicar la Agenda 2030 a Través de la Economía Social y Solidaria. Available online: http:/ / unsse. org/wp-content/uploads/2014/08/ES_Final_Position_Paper_SSE_SDGs_FAO_Geneva_es.pdf (accessed on 30 June 2017).

34. UNESCO. Rethinking Education: Towards a global Common Good? Available online: http://www.unesco. org/fileadmin/MULTIMEDIA/FIELD/Cairo/images/RethinkingEducation.pdf (accessed on 30 June 2017).

35. Ward, B.; Dubos, R. Only One Earth: The Care and Maintenance of a Small Planet; W.W. Northon \& Co.: New York, NY, USA, 1972.

36. Bardwell, L.; Monroe, M.; Tudor, M. Environmental Problem Solving; North American Association for Environmental Education (AAEE): Washington, DC, USA, 1994.

37. Huckle, J.; Sterling, S. Education for Sustainability; Earthscan Publications: Londres, UK, 1996.

38. UNESCO. Educating for a Sustainable Future: A Transdisciplinary Vision for Concerted Action. Available online: http:/ / www.unesco.org/education/tlsf/mods/theme_a/popups/mod01t05s01.html (accessed on 10 September 2017).

39. Wheeler, K.A.; Bijur, A.P. Education for a Sustainable Future. A Paradigm of Hope for the 21st Century; Kluwer Academic/Plenum Publishers: New York, NY, USA, 2000.

40. Wals, A.; van der Leij, T. Social Learning toward a More Sustainable World: Principles, Perspectives, and Praxis; United Nations University Press: New York, NY, USA, 2007.

41. United Nations Educational, Scientific and Cultural Organization (UNESCO). Education for Sustainable Development Goals. Learning Objectives; UNESCO: Paris, France, 2017.

42. United Nations Educational, Scientific and Cultural Organization (UNESCO). Education Transform Lives; UNESCO: Paris, France, 2017.

43. United Nations Educational, Scientific and Cultural Organization (UNESCO). Educación para la Ciudadanía Mundial. Preparar a los Educandos para los Retos del Siglo XXI; UNESCO: Paris, France, 2016.

44. United Nations Educational, Scientific and Cultural Organization (UNESCO). Educación para la Ciudadanía Mundial. Temas y Objetivos de Aprendizaje; UNESCO: Paris, France, 2015.

45. United Nations Educational, Scientific and Cultural Organization (UNESCO). Roadmap for Implementing the Global Action Programme on Education for Sustainable Development; UNESCO: Paris, France, 2014.

46. Murga-Menoyo, M.A.; y Novo, M. Sostenibilidad, desarrollo "glocal" y ciudadanía planetaria. Referentes de una pedagogía para el desarrollo sostenible. Teor. Educ. 2017, 29, 55-78. [CrossRef]

47. Meredith, M.; Quiroz-Niño, C.; Arando, S.; Coelho, L.S.; Silva, M.F.; Villafuerte Pezo, A.M. Social Responsibility and Transformation. In Enhancing Studies and Practices of the Social and Solidarity Economy. A Reference Handbook; Consortium York St. John University: York, UK, 2015; Chapter 7; pp. 23-25.

48. Pigem, J. La Nueva Realidad. Del economicismo a la Conciencia Cuántica; Editorial Kairós: Barcelona, Spain, 2013; p. 86.

49. Quiroz-Niño, C.; Blanco-Encomienda, F.J. Participation in decision-making processes of community development agents: A study from Peru. Community Dev. J. 2017. [CrossRef]

50. Folke, C.; Biggs, R.; Norström, A.V.; Reyers, B.; Rockström, J. Social-ecological resilience and biosphere-based sustainability science. Ecol. Soc. 2016, 21, 41. [CrossRef] 
51. Kenny, S.; Taylor, M.; Onyx, J.; Mayo, M. Challenging the Third Sector: Global Prospects for Active Citizenship; Policy Press: Bristol, UK, 2015.

52. United Nations Educational, Scientific and Cultural Organization (UNESCO). Global Citizenship Education. Topics and Learning Objectives; UNESCO: Paris, France, 2015.

53. United Nations Educational, Scientific and Cultural Organization (UNESCO). ABCs of Global Citizenship Education; UNESCO: Paris, France, 2016.

54. Pooler, M.; Harrison, R. Ethical Shopping and Price; Ethical Consumer: Manchester, UK, 2017.

55. Pahl-Wostl, C. Transition towards adaptive management of water facing climate and global change. Water Resour. Manag. 2007, 2, 49-62.

56. Bergstrom, J.C.; Randall, A. Resource Economics. An Economic Approach to Natural Resources and Environmental Policy, 4th ed.; Edward Elgar: Cheltenham, UK, 2016.

57. Dragusanu, R.; Giovannucci, D.; Nunn, N. The Economics of Fair Trade. J. Econ. Perspect. 2014, $28,217-236$. [CrossRef]

58. Murga-Menoyo, M.A. Competencias para el desarrollo sostenible: Las capacidades, actitudes y valores meta de la educación en el marco de la Agenda global post-2015. Foro de Educación 2015, 13, 55-83. [CrossRef]

59. Murga-Menoyo, M.A.; Novo, M. Sostenibilizar el curriculum. La Carta de la Tierra como marco teórico. Edetania 2014, 46, 163-179.

60. Delors, J. Learning: The Treasure Within. 1996. Available online: http://unesdoc.unesco.org/images/0010/ 001095/109590eo.pdf (accessed on 18 November 2017).

61. Novo, M.; Murga-Menoyo, M.A. The processes of integrating sustainability in Higher Education curricula: A theoretical practical experience regarding key competences and their cross-curricular incorporation into degree courses. In Transformative Approaches to Sustainable Development at Universities; Leal Filho, W., Ed.; Springer: New York, NY, USA, 2015; pp. 119-136. [CrossRef]

(C) 2017 by the authors. Licensee MDPI, Basel, Switzerland. This article is an open access article distributed under the terms and conditions of the Creative Commons Attribution (CC BY) license (http:/ / creativecommons.org/licenses/by/4.0/). 